\title{
12. SITE SURVEY REPORT FOR SITE 142
}

\author{
Robert Embley and Dennis E. Hayes, Lamont-Doherty Geological \\ Observatory of Columbia University, Palisades, New York ${ }^{1}$
}

\section{INTRODUCTION}

In August of 1970, on a leg from Trinidad to the Ivory Coast, the R/V Robert D. Conrad completed a survey on the southern edge of the Ceara Rise (Figure 1) in preparation for drilling which took place the following November. The primary purposes of the survey were to locate the optimum site for drilling into the abyssal plain sediments and rise flank and to provide a regional geologic setting to aid in the interpretation of the drilling results. A tentative site had originally been chosen on the basis of data collected during the $\mathrm{R} / \mathrm{V}$ Vema Cruise 25 . These data are also included in this report.

\section{REGIONAL SETTING}

The Ceara Rise is a large topographic feature and has a known areal extent in excess of 5000 square miles. As shown in Figure 1, the rise lies to the northeast of the mouth of the Amazon River and is the physiographic division between the Ceara Abyssal Plain to the south and the Demerara Abyssal Plain to the north and northeast (Heezen and Laughton, 1963). The southern edge of the Ceara Rise lies about 100 miles due north of the North Brazilian Ridge described by Hayes and Ewing (1970).

We mapped the rise primarily on the basis of the characteristic sediment sequence observed on the reflection records. This sediment sequence has a subsurface extent which is somewhat larger than the topographic feature. For instance, the separation of the rise into two pieces (see Figure 1) may only be superficial; there is some indication that these two segments are connected beneath the Pleistocene abyssal plain sediments. Figure $2 \mathrm{a}$ illustrates the track line configuration of the detailed survey.

\section{TOPOGRAPHY}

Figure $2 \mathrm{~b}$ is a topographic map of the detailed survey area. The southern edge of the rise in this area is outlined by the $2290-\mathrm{fm}$ contour. The total relief in this area is about $600 \mathrm{fm}$. The main features of interest are (1) the northwest-southeast trend of the topography of the rise, (2) the steep southern flank of the rise particularly in the region from about $42^{\circ} 50^{\prime} \mathrm{W}$ to $43^{\circ} 20^{\prime} \mathrm{W}$, (3) the subtle depressions in the abyssal plain which may mark the paths of sediment transport, (4) the topographic terrace developed between the 2000- and 2100-fm contours on the southwestern "corner" of the rise, and (5) the unusual microtopography found in selected areas.

\section{GRAVITY AND MAGNETICS}

Figures $2 \mathrm{c}$ and $2 \mathrm{~d}$ show, respectively, the free-air gravity and the residual total intensity magnetic anomalies for the

\footnotetext{
${ }^{1}$ Contribution No. 1817
}

survey area. The gravity anomalies tend to coincide with the regional topography and the magnetic anomalies, which are a maximum of about 500 gammas peak to peak, are readily contoured subparallel to the topographic trend of the ridge. The basement cannot be followed from the plain onto the rise, thus making the interpretation of the gravity and magnetic observations more difficult. Strong indications of occasional reflections from the basement are observed on the seismic profiles, and the presence of relatively high-amplitude, lineated magnetic anomalies support the suggestion that magnetic basement is not deeply buried. The free-air gravity anomaly associated with the rise $(20 \mathrm{mgal} / \mathrm{km}$ of rise) is significantly smaller (by about $20 \mathrm{mgal}$ ) than that expected either from an uncompensated sediment pile or from an uncompensated basement ridge covered with sediment. This observation implies some gravimetric compensation at depth, but further speculation regarding the details of the underlying crustal configuration is unwarranted without further knowledge of the basement trends.

\section{SEISMIC REFLECTION RECORDS}

Low-frequency air gun reflection records over the rise (Figures 3-5) typically show a pile of sediments which has a minimum thickness of $1 \mathrm{~km}$. Basement (Layer 2) was recorded only intermittently in the survey area as illustrated at miles 2132 and 2237 (Figure 4). Figure 1 shows the locations of such possible basement highs throughout the rise, and they appear to trend roughly along the topographic high. In some places, such as mile 2073 in profile B-C (Figure 3), the steep scarp may be controlled by the basement relief. A large positive magnetic anomaly is also present along this scarp region as shown in Figure 2c.

Several sediment units which form the abyssal plain characteristically contain many closely-spaced reflectors, whereas, the rise sediment sequence is mostly acoustically homogeneous, containing only intermittent diffuse reflectors. However, seismic penetration of the rise sequence is less than that of the abyssal plain, indicating more energy attenuation by the rise sediment at this recording frequency.

Profiles A-B, B-C (Figure 3), and C-D (Figure 4) show the typical abyssal plain sequence in the area. There is an upper reflective zone, then a more transparent zone, then another reflective zone. This is followed by a transparent zone and finally a faint reflective zone which seems to lie close to basement. The top of the second reflective zone defines a prominent reflector which has been continuously mapped by Hayes and Ewing (1970) through all of the Ceara Abyssal plain except its extreme southwestern portion. 


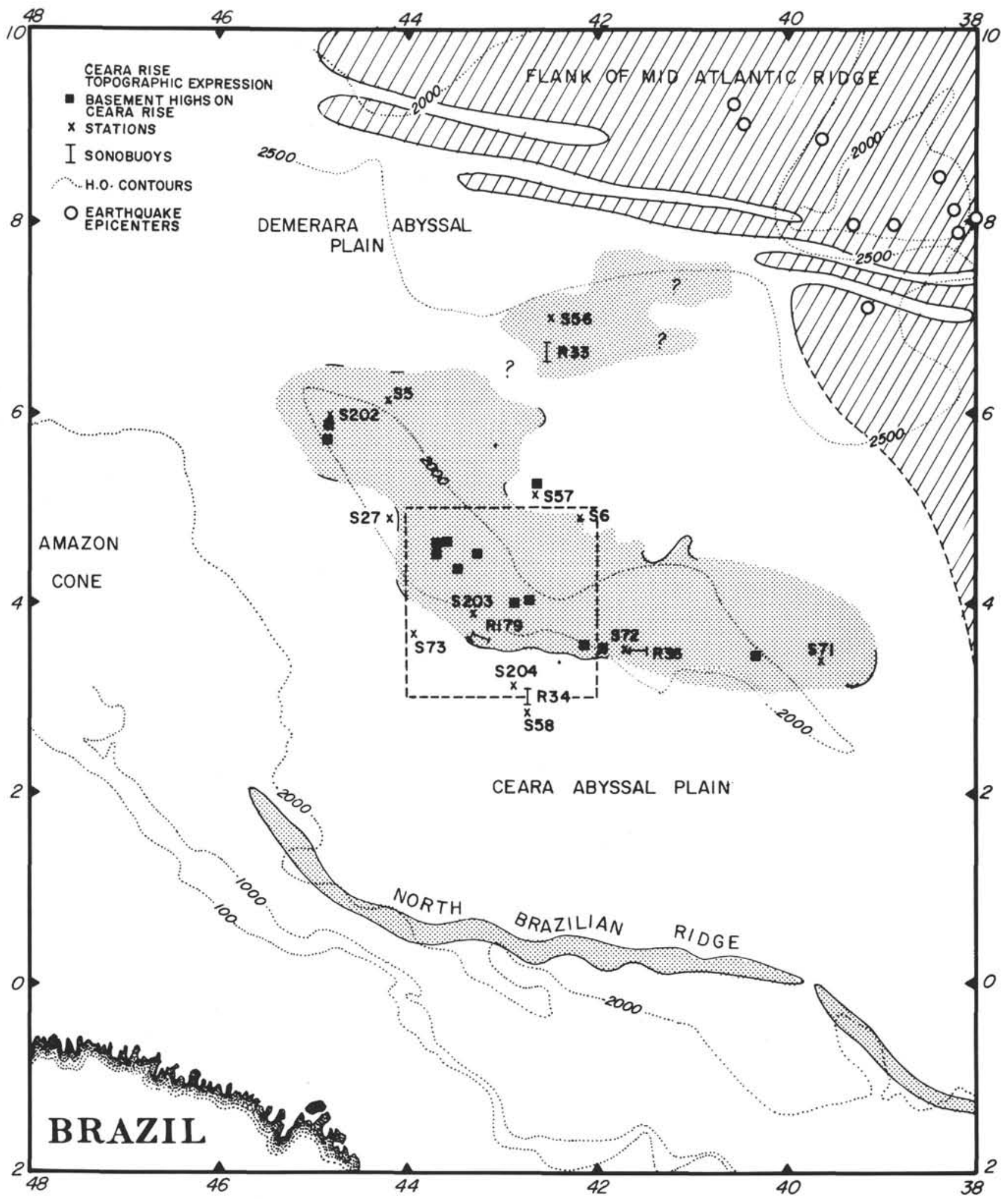

Figure 1. Physiographic map showing regional location of survey area (dashed box). The black line segments indicate profiler crossings. The fracture zones to the north are after Fox (1972), and the epicenters are the courtesy of Lynn Sykes. Contours are from USNAVOCEANO map 15254-7 Misc. The structural outline of the North Brazilian Ridge is from Hayes and Ewing (1970). 


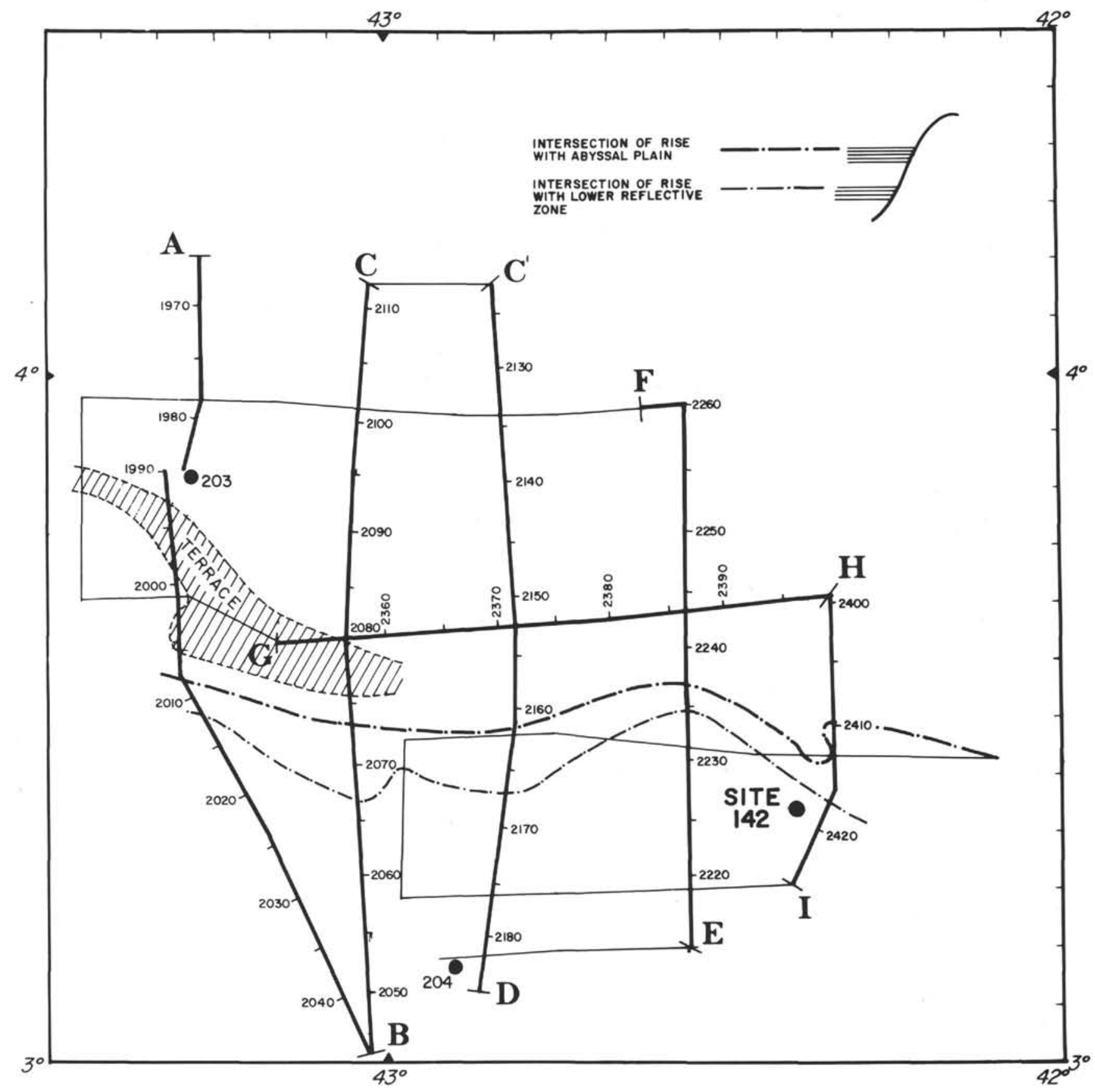

Figure 2a. Physiographic and profiler location map for Site 142 survey area. Numbers beside track are miles along the track for that leg of the R. V. Conrad and concur with the mileage for Figures 3-6.

As seen in all the profiles, but most clearly illustrated in E-F (Figure 4) and G-H-I (Figure 5), the upper reflective zone onlaps the rise sequence. The relationship of the upper transparent zone and intermediate reflective zone is not so clear. However, many profiles indicate a slight apparent shoaling of the top of the second reflective zone towards the rise, and profile E-F (Figure 4) strongly suggests continuity of these two acoustic intervals (not necessarily lithologic) from the plain onto the rise. Profile G-H-I (Figure 5) also illustrates this. 


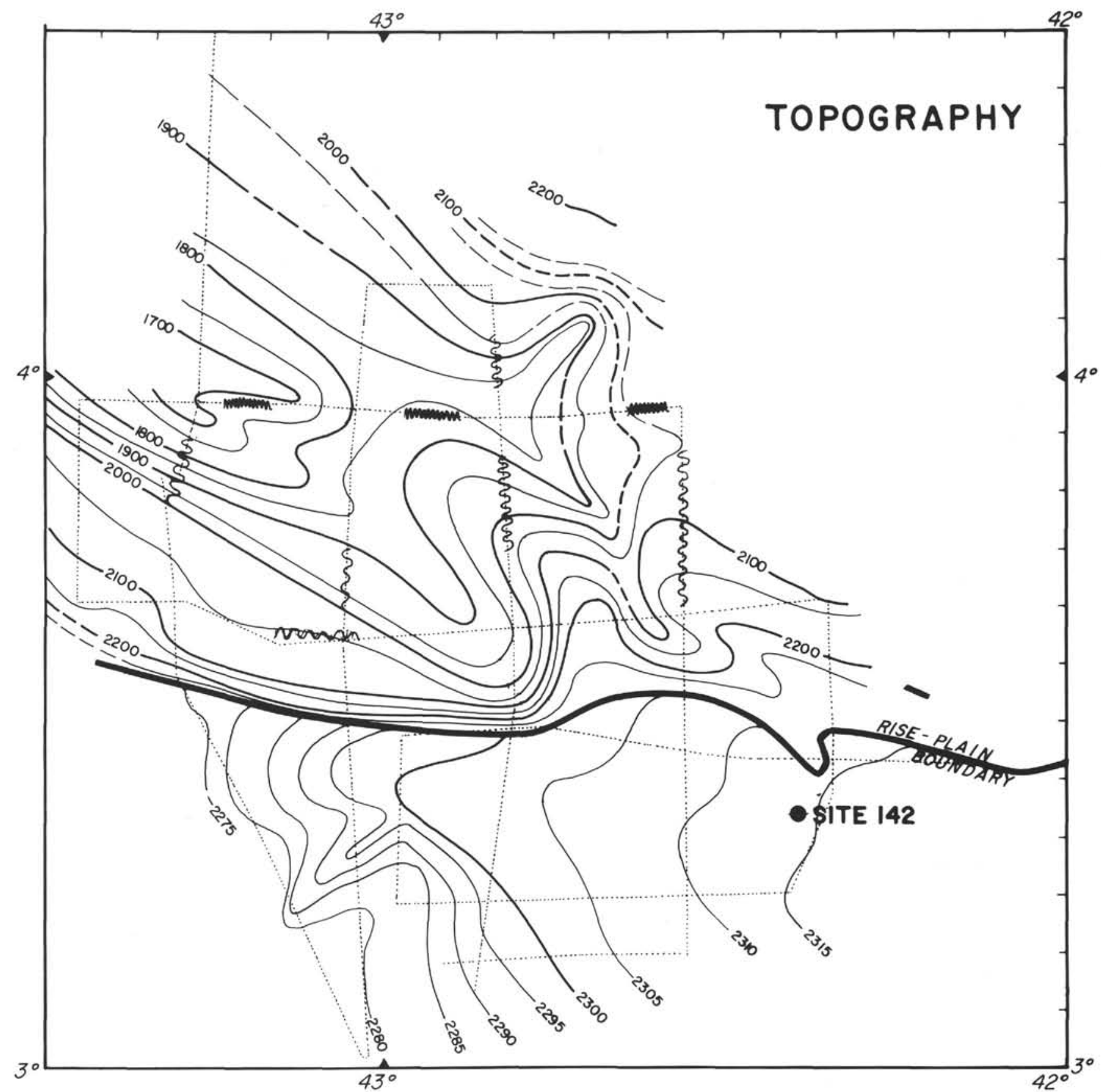

Figure 2b. Bathymetric map for the survey area. The contour interval over the rise is 50 fm (uncorrected) and over the abyssal plain is $5 \mathrm{fm}$. The wiggly lines along the track indicate the presence of hyperbolated bottom which is discussed in the text and seen in Figures 3 and 6. The short wiggles indicate wave lengths on the order of 100 to 150 meters, and the long wiggles on the order of 200 to 300 meters.

A sonobuoy (RC13-179, Table 1) shot on the terracelike feature, recorded a sequence of low-velocity sediments overlying material with a refraction velocity of about 4.5 $\mathrm{km} / \mathrm{sec}$, which is high enough to be layer 2 (oceanic basalt). The depth of the $4.5 \mathrm{~km} / \mathrm{sec}$ layer was close to that of the deepest reflector observed over the rise, which is best seen between miles 2387 and 2412 in profile G-H-I. This reflector may represent a unit which directly overlies and conforms to basement. Results of other sonobuoys in the area are shown in Table 1, and sonobuoy station R36 also indicates more than $0.9 \mathrm{~km}$ of low-velocity sediments are present on the rise.

The $3.5 \mathrm{kHz}$ records taken over the rise intermittently record an interesting hyperbolated bottom. The wavelength of the hyperbolae (Figures $2 \mathrm{~b}$ and 6 ) is distinctly longer for north-south tracks $(200-300 \mathrm{~m})$ than for those on an east-west heading $(100-150 \mathrm{~m})$, and on some of the later traverses their spacing is very regular. The slope directly to 


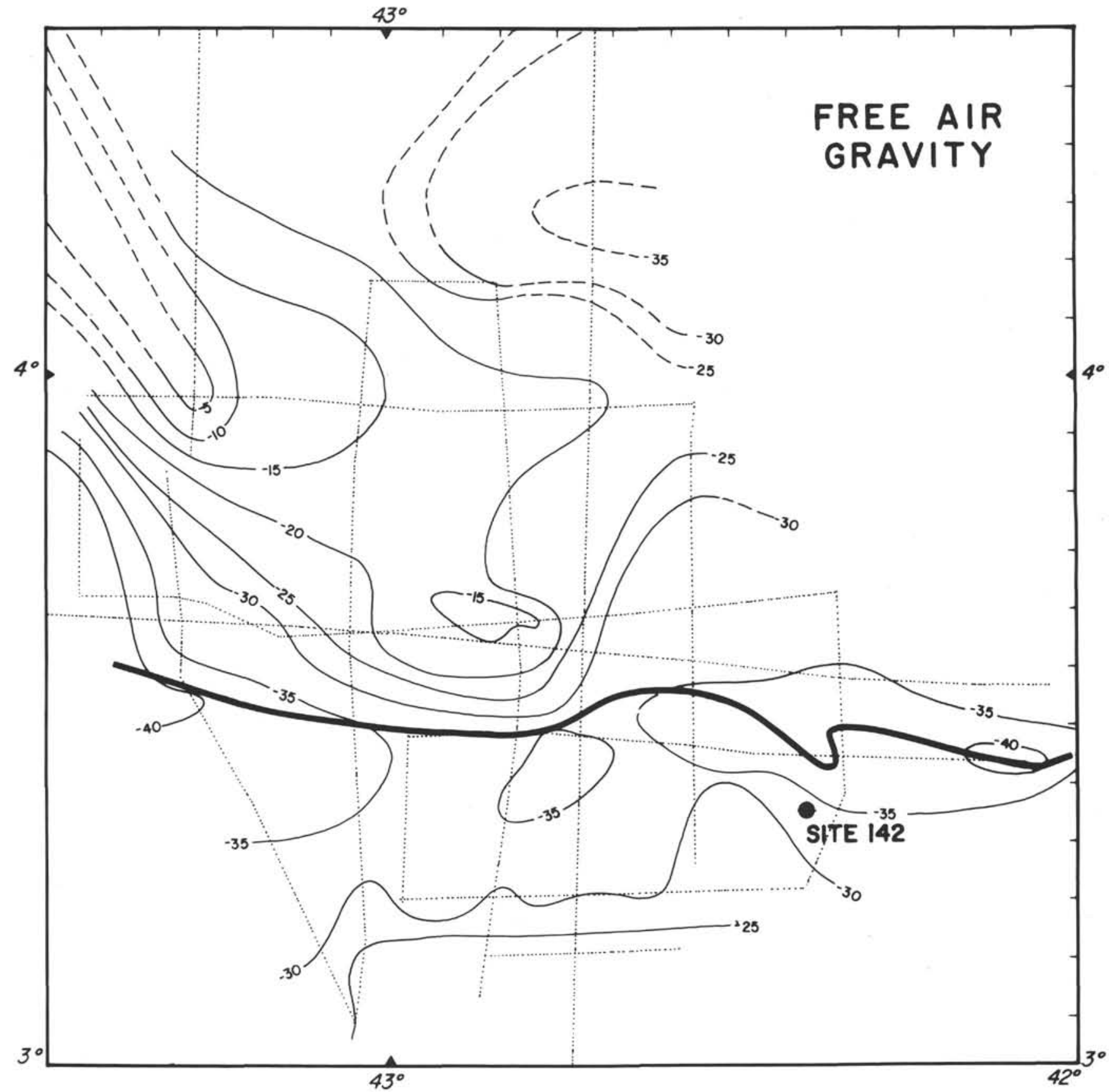

Figure 2c. Free-air gravity anomaly map over survey area. The contour interval is $5 \mathrm{mgal}$.

the north of the terrace is characterized by these hyperbolae (miles 1983-1992 and 2082-2087; see Figure 3), and a current meter measurement taken at station 203 recorded a southwesterly bottom current of $11 \mathrm{~cm} / \mathrm{sec}$. The origin of this bottom type is undoubtedly related to bottom currents (North Atlantic Deep Water), but the details of the process of formation of the micro-relief are more elusive. The current measurement suggests a contemporaneous formation; bottom photographs taken in the same locality show no convincing evidence for strong currents. However, the tangency of the hyperbolae to the present sea floor (in all but one case) implies an age probably no older than Pleistocene (the currents may have been stronger in the glacial stages). There also is an uncertainty as to whether these features are due to erosion or depositional processes, although the latter explanation is preferred because of the inferred periodicity of the features. The evidence for large-scale outcropping of older material on the southern edge of the rise (for example, Miocene age of piston core V25-62 and profile C-D, Figure 4) suggests erosional and/or tectonic processes for this section.

\section{PISTON CORES}

Locations of coring stations in the area are shown in Figure 1 and listed in Table 2. Cores taken in the surrounding abyssal plains typically show a series of latest Pleistocene 


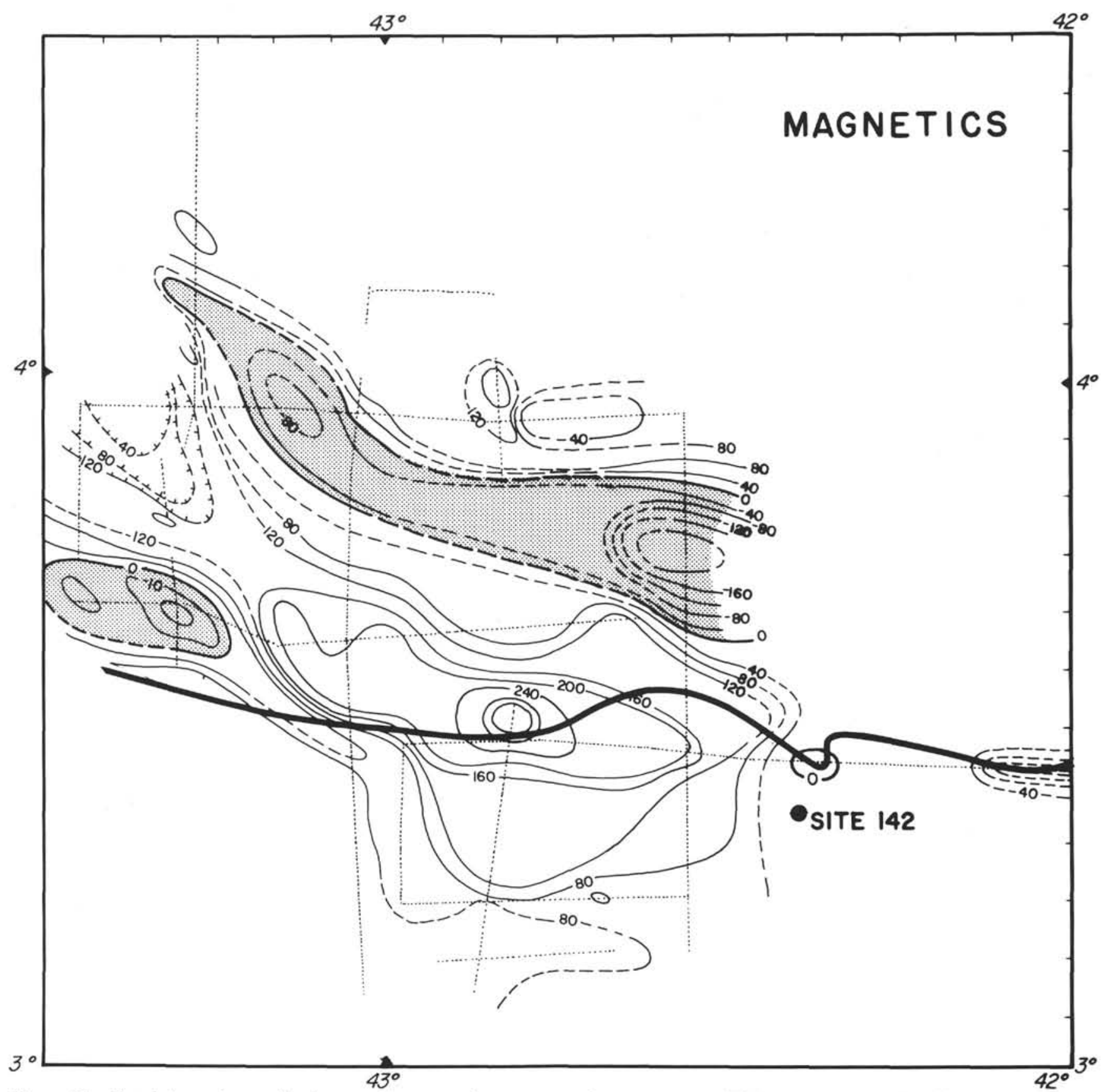

Figure $2 \mathrm{~d}$. Total intensity residual magnetic anomaly map over the survey area. The contour interval is 40 gammas and the negative areas are indicated by stippling. The control here is less than for the gravity and topography because of instrumental problems.

turbidites interlayered with gray hemipelagic clays overlain by 20 to $70 \mathrm{~cm}$ of brownish Holocene foraminiferal marl. In most cases there is a characteristic "rusty" zone at the Holocene-Pleistocene boundary (Damuth and Fairbridge, 1970). Cores taken on the southern part of the rise, in and near the survey area, are typically Holocene and late Pleistocene calcareous pelagic sediments (for example, cores V25-63, RC13-184). V25-62 contains latest Lower Miocene foraminiferal ooze that may be contemporaneous with some of the drilled section. (See Chapter 9, this volume.)
Cores taken on the northwestern flanks of the rise (RC8-5, RC13-183 and V25-47) at depths slightly shallower than the Demerara Plain to the north, contain terrigenous components. For example, RC $8-5$ has a $10-\mathrm{cm}$ graded turbidite plus several thin sand-silt laminae consisting of quartz and feldspars (Damuth and Fairbridge, 1970). The material in these cores probably originated from the mouth of the Amazon River and reached this area by flow interaction between turbidity currents and bottom currents. 

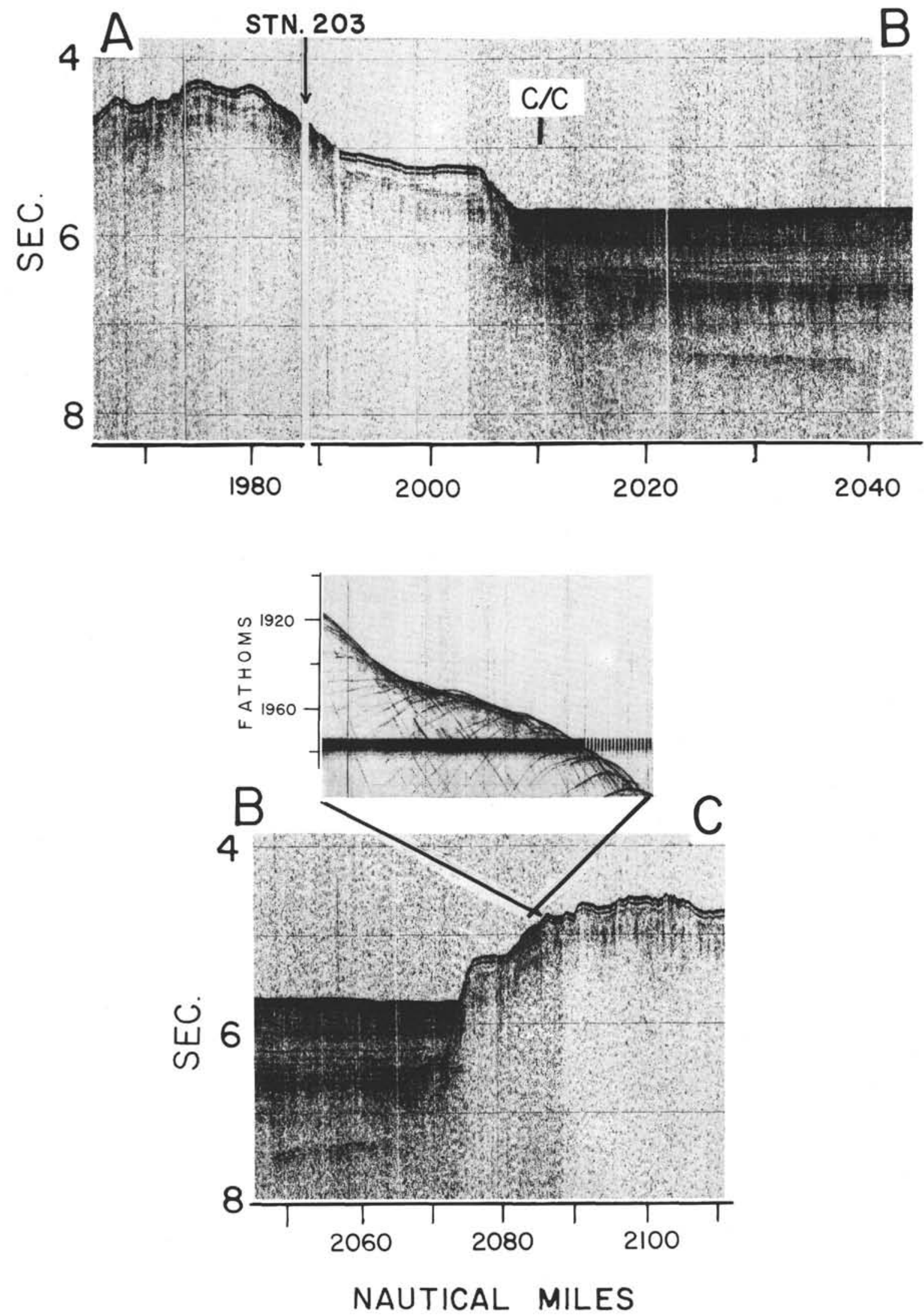

Figure 3. Profiles $A-B$ and B-C. See Figure 2a for location. The offset on profile B-C is a section of $3.5 \mathrm{kHz}$ record showing the hyperbolated bottom. The vertical scale for the profiles is two-way travel time. $c / c$ indicates a course change. 

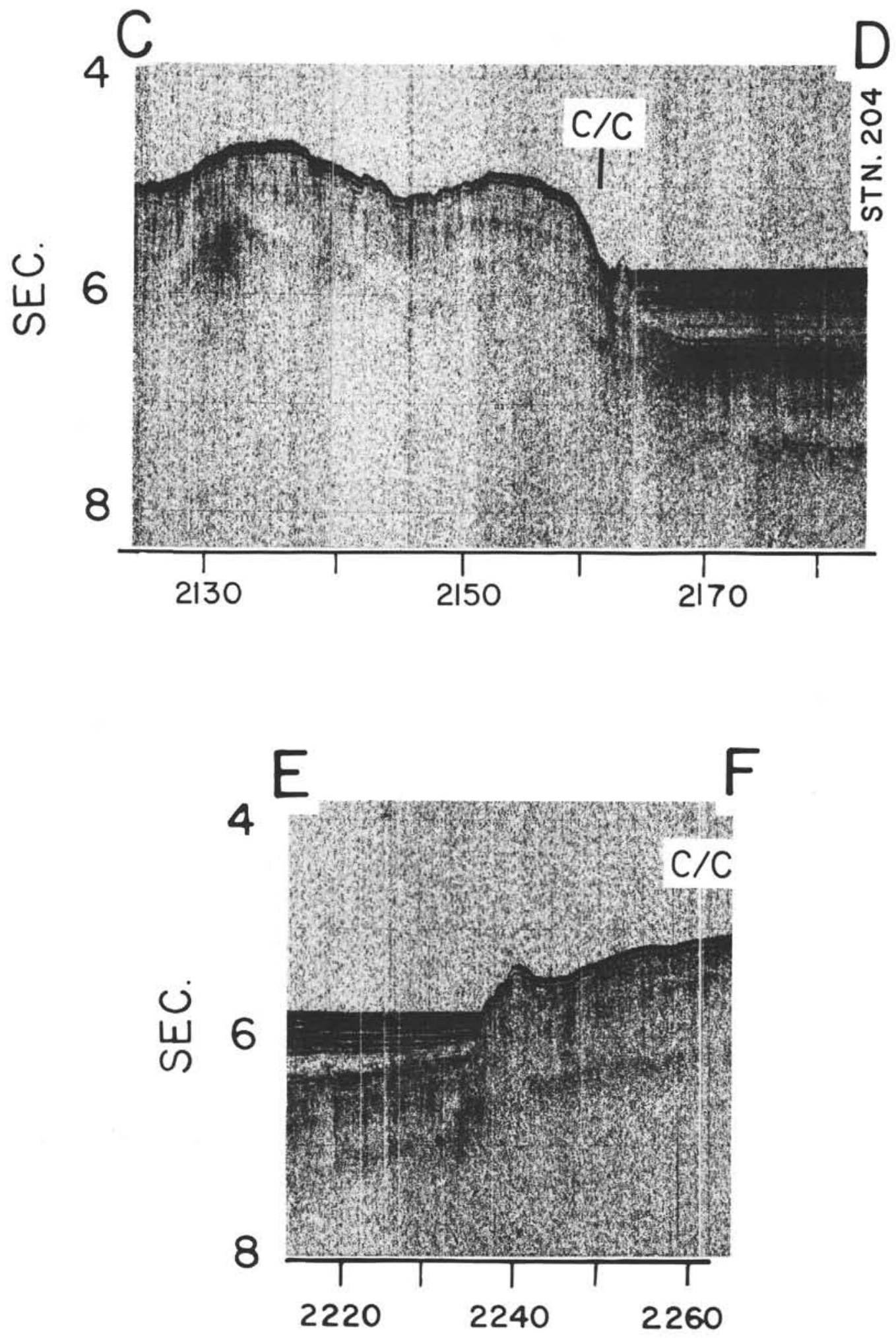

\section{NAUTICAL MILES}

Figure 4. Profiles $C-D$ and E-F. See Figure $2 a$ for their location. 


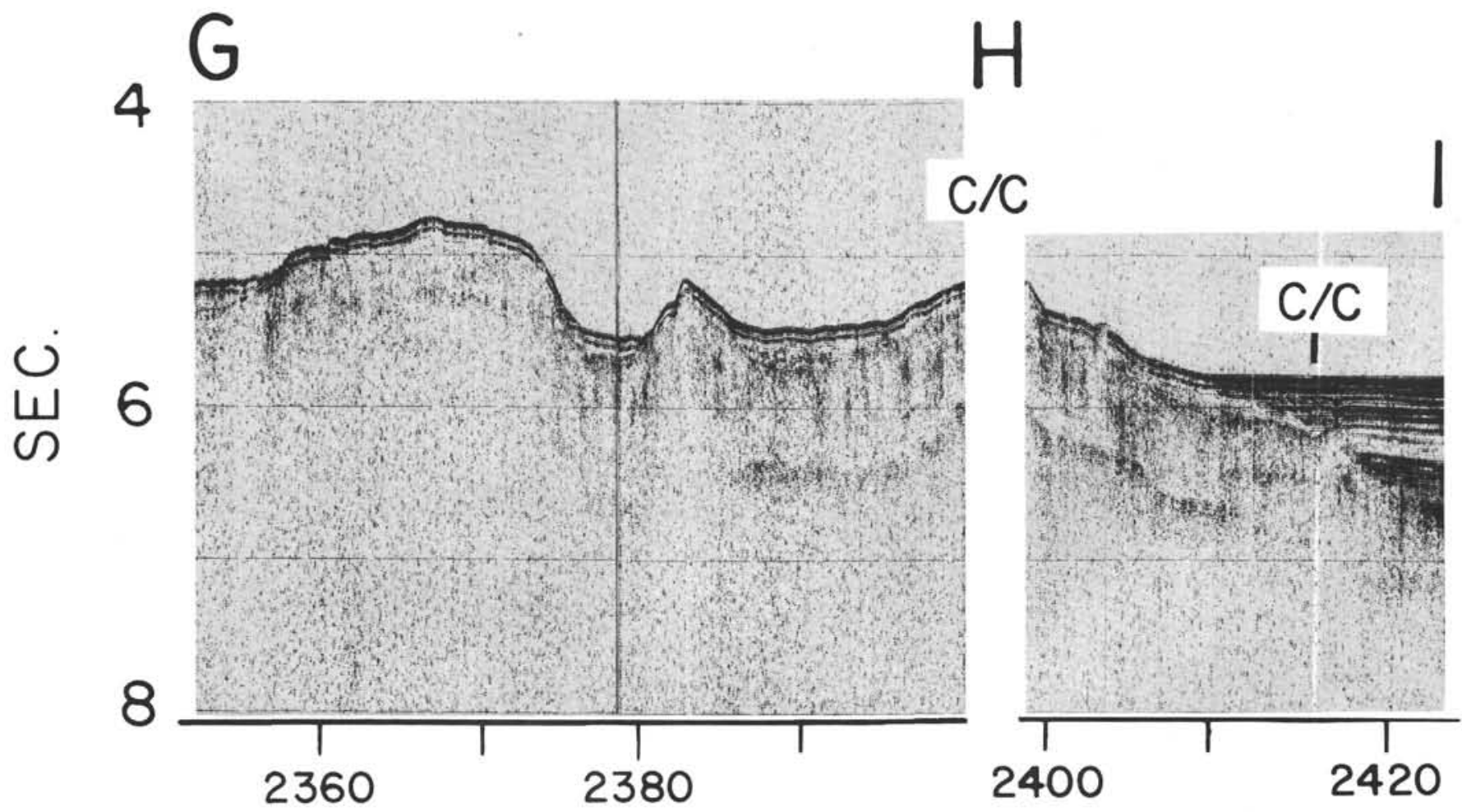

\section{NAUTICAL MILES}

Figure 5. Profile G-H-I. See Figure 2a for location.

TABLE 1

Sonobuoys in the Vicinity of the Ceara Rise

\begin{tabular}{|c|c|c|c|c|}
\hline Cruise & Buoy No. & $\begin{array}{l}\text { Interval } \\
\text { (sec) }\end{array}$ & $\begin{array}{l}\text { Interval } \\
\text { Velocity } \\
(\mathrm{km} / \mathrm{sec})\end{array}$ & $\begin{array}{c}\text { Thickness } \\
\text { (sec) }\end{array}$ \\
\hline V25 & R33 & $\begin{array}{l}6.00-6.75 \\
6.77 \text { Refraction }\end{array}$ & $\begin{array}{l}2.70 \\
4.79\end{array}$ & 0.75 \\
\hline V25 & R34 & $\begin{array}{l}5.73-6.20 \\
6.20-6.55 \\
6.55-7.10\end{array}$ & $\begin{array}{l}1.66 \\
1.97 \\
2.20\end{array}$ & $\begin{array}{l}0.47 \\
0.35 \\
0.55\end{array}$ \\
\hline V25 & R36 & $\begin{array}{l}4.54-5.06 \\
5.06-5.47\end{array}$ & $\begin{array}{l}1.70 \\
2.49\end{array}$ & $\begin{array}{l}0.50 \\
0.41\end{array}$ \\
\hline $\mathrm{RC} 13$ & R179 & $\begin{array}{l}5.202-5.934 \\
5.934-6.216 \\
6.216-6.431 \\
6.431-\text { Refraction }\end{array}$ & $\begin{array}{l}1.955 \\
2.042 \\
2.841 \\
4.50\end{array}$ & $\begin{array}{l}0.73 \\
0.29 \\
0.21\end{array}$ \\
\hline
\end{tabular}

Core RC13-186 (Station 204, profile C-D) was taken on the Ceara Abyssal Plain within the survey area. The left side of Figure 7 shows the approximate acoustic sequence in which it was taken. The subbottom reflectors in this area are directly correlatable with sand layers sampled in the cores.

\section{ACKNOWLEDGMENTS}

This work was supported by the Office of Naval Research contract N00014-67-A-0108-004 and the National Science Foundation grant GA 27281. We wish to acknowledge the officers and crew of the R/V Conrad and in particular Mr. R. Markl who served as co-chief scientist and was also the author of the topographic map. J. Damuth provided the core descriptions and S. Eittreim and G. Bryan reviewed the manuscript.

\section{REFERENCES}

Damuth, J. and Fairbridge, R., 1970. Equatorial Atlantic deep-sea arkosic sands and ice-age aridity in tropical South America. Bull. Geol. Soc. Am., 81189.

Fox, P. J., 1971. The geology of some Atlantic fracture zones, Carribbean escarpments and the nature of the oceanic-basement and crust. Ph.D. thesis, Columbia University, New York.

Hayes, D. and Ewing, M., 1970. North Brazilian Ridge and adjacent continental margin. Bull. Am. Assoc. Petrol. Geologists., 54, 2120.

Heezen, B. and Laughton, A., 1963. Abyssal plains. In The Sea, (M. Hill, ed.), Wiley Interscience, New York, 3, 312-364. 
TABLE 2

Cores in the Vicinity of the Ceara Rise

\begin{tabular}{|c|c|c|c|c|c|c|}
\hline Cruise & Station Number & Core Number & Length & $\begin{array}{l}\text { Depth } \\
(\mathrm{fm})\end{array}$ & Basal Age & Lithology $^{a}$ \\
\hline V25 & 56 & 47 & 919 & 2420 & Late Pleistocene & $\begin{array}{l}\text { Foram marls with a few terrigenous silt and sand } \\
\text { laminae }(<5 \mathrm{~cm}) \text {. }\end{array}$ \\
\hline V25 & 57 & 48 & 971 & 2500 & Late Pleistocene & $\begin{array}{l}\text { Brown foram marl with rusty zone at base }(63-70 \mathrm{~cm}) \\
\text { overlying hempelagic clay with several terrigenous } \\
\text { turbidites which are largely gray homogeneous clay } \\
\text { with several silt-sand beds at bases. }\end{array}$ \\
\hline V25 & 58 & 49 & 822 & 2292 & Late Pleistocene & $\begin{array}{l}\text { Brown foram marl with rusty zone at base }(60 \mathrm{~cm}) \\
\text { overlying hemipelagic gray clay with interbedded } \\
\text { graded sand/silt beds. }\end{array}$ \\
\hline V25 & 71 & 62 & 345 & 2300 & Miocene & Yellowish gray foram ooze. Semi-indurated \\
\hline V25 & 72 & 63 & 780 & 1715 & Late Pleistocene & Foram marls-no terrigenous components \\
\hline V25 & 73 & 64 & 368 & 2255 & Late Pleistocene & $\begin{array}{l}\text { Brown foram marl with basal rusty zone }(58 \mathrm{~cm}) \text { over } \\
\text { gray hemipelagic clay with several thin }(<5 \mathrm{~cm}) \\
\text { sand-silt beds. }\end{array}$ \\
\hline V18 & 27 & 22 & 570 & 2207 & Late Pleistocene & $\begin{array}{l}\text { Brown foram marl with rusty zone }(58 \mathrm{~cm}) \text { over gray } \\
\text { hemipelagic clay with several sand-silt beds, some } \\
\text { graded, } 5-130 \mathrm{~cm} \text {. }\end{array}$ \\
\hline $\mathrm{RC} 8$ & 5 & 5 & 803 & 2410 & Late Pleistocene & $\begin{array}{l}\text { Brown foram marl with basal rusty zone }(45 \mathrm{~cm}) \text { over } \\
\text { gray hemipelagic clay with numerous thin sand-silt } \\
\text { laminae, generally }<1 \mathrm{~cm} \text { thick. }\end{array}$ \\
\hline $\mathrm{RC} 8$ & 6 & 6 & 592 & 2422 & Late Pleistocene & $\begin{array}{l}\text { Brown foram marl with rusty zone }(69 \mathrm{~cm}) \text {. Gray } \\
\text { hemipelagic clay with a few sand silt lenses }(<1 \mathrm{~cm} \\
\text { thick). }\end{array}$ \\
\hline $\mathrm{RC} 13$ & 202 & 183 & 1027 & 1990 & Late Pleistocene & $\begin{array}{l}\text { Brown foram marl with basal rusty zone }(65 \mathrm{~cm}) \text {, } \\
\text { overlying gray hemipelagic clay. }\end{array}$ \\
\hline $\mathrm{RC} 13$ & 203 & 184 & 811 & 1840 & Late Pleistocene & Light brown foram marls \\
\hline $\mathrm{RC} 13$ & 204 & 185 & 896 & 2289 & Late Pleistocene & $\begin{array}{l}\text { Brown foram marl with rusty zone }(48 \mathrm{~cm}) \text { over gray } \\
\text { hemipelagic clays with several sand-silt beds, many } \\
\text { graded } 5-170 \mathrm{~cm} \text { thick. }\end{array}$ \\
\hline $\mathrm{RC} 13$ & & 186 & 630 & & & Similar to 185 \\
\hline
\end{tabular}

${ }^{a} A l l$ silt-sand layers mentioned are terrigenous. 


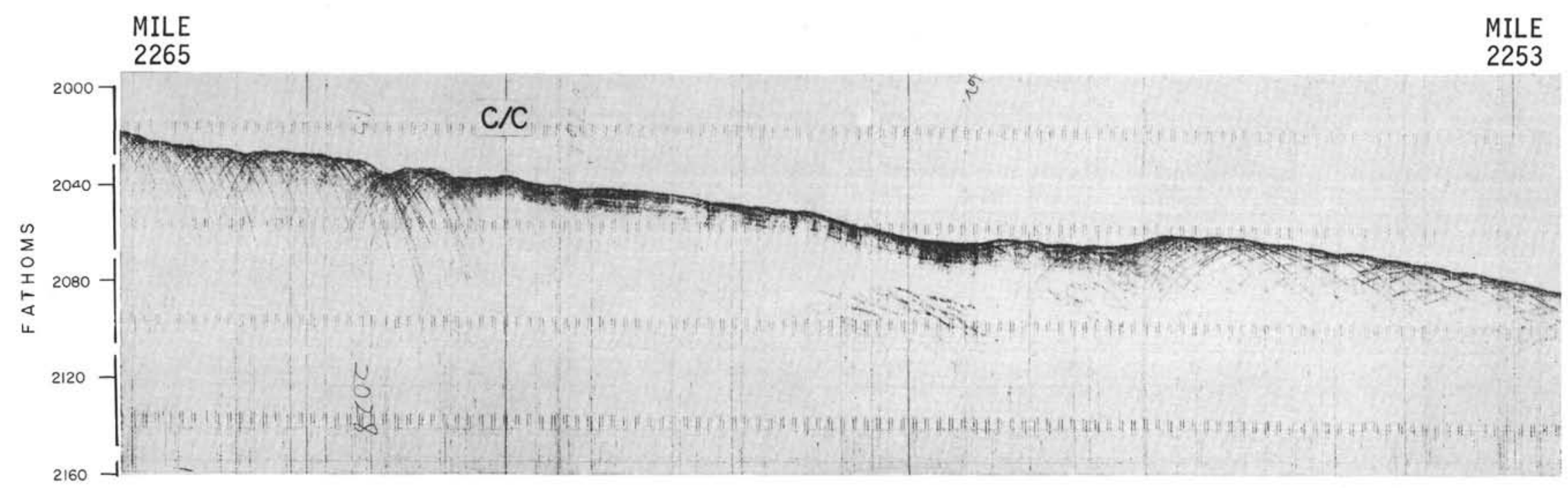

Figure 6. $3.5 \mathrm{kHz}$ record on top of rise. See Figure 2 a for location. Note the distinct shortening in wavelength after the course change. 


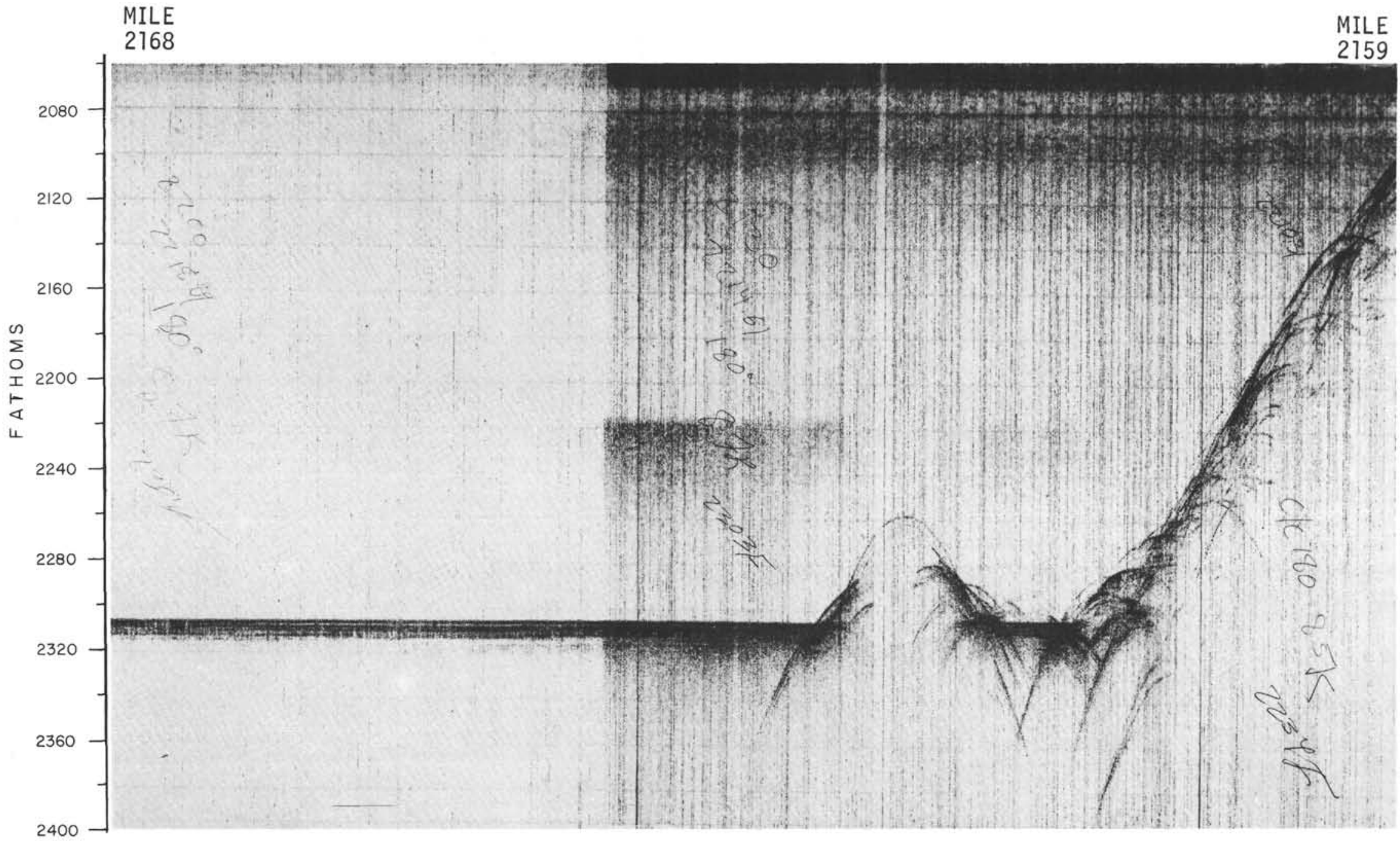

Figure 7. $3.5 \mathrm{kHz}$ record of Ceara Abyssal Plain and adjacent southern flank of the Ceara Rise. See Figure 2a for location of profile. 